\title{
Okul Öncesi Alternatif Düşünme Stratejilerinin Desteklenmesi Programının Öğretmenlerin Bakış Açısıyla İncelenmesi*
}

\author{
The Assessment of Preschool Promoting Alternative Thinking Strategies Program \\ in Terms of Teachers' Views
}

\author{
Şakire OCAK KARABAY* \\ Tuğçe Burcu ARDA TUNCDEMIR ${ }^{* *}$
}

\section{Öz}

Bu makalenin amacı okul öncesi dönemde yaygın olarak kullanılan bilimsel açıdan pek çok defa etkililiği kanıtlanmış, önleyici müdahale programlarından biri olan Okul Öncesi Alternatif Düşünme Stratejilerinin Desteklenmesi (ADSD) (The Preschool Promoting Alternative Thinking Strategies Curriculum - PATHS) (Domitrovich, Greenberg, Cortes ve Kusche, 2005) programının içeriğini, amaçlarını, etkililiğini, katkılarını ve güçlüklerini, öğretmenlerin görüşleri doğrultusunda değerlendirmektir. Çalışma grubunu 10 okul öncesi öğretmeni oluşturmuştur. Araştırma modelinde nitel ve nicel yöntemlere başvurulmuştur. Araştırmada veri toplama aracı olarak "Öğretmen Görüşme Formu", "Öğretmen Memnuniyet Formu” ve "Öğretmen Bilgi Formu" kullanılmıştır. Elde edilen veriler betimsel analiz yöntemiyle değerlendirilmiştir. Öğretmenlerin ADSD Programının içeriğine, amaçlarına ve katkılarına yönelik görüşleri incelendiğinde programın okul öncesi eğitim programını zenginleştirmede oldukça etkili bir işleve sahip olduğu ifade edilmiştir. Öğretmenler programın çocukların benlik saygısını, problem çözme becerilerini ve duygularına yönelik farkındalıklarını ve davranışlarını geliştirdiği konusunda yüksek oranda memnuniyetlerini dile getirmişlerdir. Ayrıca öğretmenlerin programın kendi duygu düzenlemelerini sağlamada ve sorunlarla baş etmede kişisel yaşamlarına katkıda bulunduğu konusunda hem fikir oldukları saptanmıştır.

* Bu çalışma Yrd. Doç. Dr. Şakire OCAK danışmanlığında Tuğçe Burcu ARDẢnın Ege Üniversitesi Sosyal Bilimleri Enstitüsünde hazırladığı Alternatif Düşünme Stratejilerinin Desteklenmesi Programının Okul Öncesi Çocuklarının Sosyal Becerileri Üzerinde Etkililiğinin Değerlendirilmesi isimli yüksek lisans tezinden üretilmiştir.

** Doç. Dr., Ege Üniversitesi, sakire.ocak@ege.edu.tr

*** Uzm. Doktora Öğrencisi, Penn State Universitesi, tba113@psu.edu 
Anahtar kelimeler: Önleyici Müdahale Programları, Adaptasyon, Yaygınlaştırma, Etkililik, Problem Çözme

\begin{abstract}
The aim of this study is to assess in the view of teacher's thoughts on the content, the aims, the effectiveness, the difficulties of implementation, and the contributions of the Preschool PATHS Program (The Preschool Promoting Alternative Thinking Strategies Curriculum PATHS) (Domitrovich, Greenberg, Cortes ve Kusche, 2005) which is one of the preventive intervention programs proved scientifically to be efficient many times and used commonly. Participant group consisted of ten preschool teachers. Quantitative and qualitative methods were used in the study. As data collection tools, Teacher Interviews, The Teacher Satisfaction Survey and the Teacher Self Report are used in this research. Collected data was assessed by using descriptive analysis method. The program has a quite effective function in enrichment of preschool curriculum when teachers' views about effectiveness, the content, aims and contributions of the Preschool PATHS program were considered. Teachers at a high ratio expressed their satisfaction that the program improved children's self-esteem, problem solving skills and their awareness for their feelings and their behaviors. Moreover, it was determined that teachers were in agreement that this program provided contributions in their personal life in terms of their own emotion regulations and problem solving.
\end{abstract}

Keywords: Preventive Intervention Programs, Adaptation, Dissemination, Effectiveness, Problem Solving

\title{
Giriş
}

Etkililiği bilimsel olarak kanıtlanmıș olan önleyici müdahale programlarının günlük uygulamalardaki etkililiklerinin değerlendirilmesi amacıyla geniş kapsamlı yaygınlaştırma çalışmalarına ihtiyaç duyulduğu sıklıkla vurgulanmaktadır. Bu bağlamda bu programların etkililikleri ve yeterlilik ile ilişkili çalışmaların farklı topluluklarda sınanması gerektiği vurgulanmaktadır (Weisberg ve Greenberg, 1998). Bu aşamada araştırmacıların üzerinde durdukları nokta programların içeriğinde olması öngörülen unsurların değiştirilmeden programlara yüksek düzeyde bağlılık göstererek sınanmasıdır. Ancak bu süreçte bazı kritik noktalara dikkat etmek gerekmektedir. Öncelikle söz konusu programın uygulanacak toplum için uygun olup olmadığ 1 değerlendirilmelidir. Ayırca söz konusu toplum için bu programda herhangi bir adaptasyona ihtiyaç duyulup duyulmadığına karar verilmelidir. $\mathrm{Bu}$ adaptasyon sürecinde hangi boyutta değişiklikler yapılacağı ve programa ne kadar bağlı kalınacağı da tartışılmalıdır (O’Connor, Small ve Cooney, 2007; Weisberg ve Greenberg, 1998; "U.S. Department of Health and Human Services, 2002" . Diğer taraftan Hill, Maucione ve Hood (2007) program geliştiricilerin, söz konusu programların özel içeriğine bağlı kalarak uygulamaları gerçekleştirmek gerekliliği üzerinde durduklarını açıklamışlardır. Uzmanlar yalnızca bu koşullarda programın beklenen özel etkiyi ve sonucu yaratacağına inanmaktadırlar. Nitekim araştırmacılar uygulama bulgularında programın içeriğine ve dozuna yüksek derecede bağlılık gösterildiği zaman sınıf ortamının niteliğinin değiștiğini belirtmektedirler (Conduct 
Problems Prevention Research Group (CPPR), 1999). Diğer taraftan bazı araştırmacılar ise bir toplum için oluşturulan bir programın diğer toplumun ihtiyaçları ile örtüşemeyeceği bazı durumlar olabileceğini açılklamışlardır. Böyle durumlarda adaptasyonun bir gereksinim olabileceği belirtilmiştir (O’Connor, vd., 2007).

Bu konuda O'Connell, Boat ve Warner (2009) uygulama sürecinde üç alternatif uygulama tanımlayarak farklı yaklaşımların tercih edilebileceğini ifade etmektedir. Birinci yaklaşımda söz konusu programı direk benimseyerek orijinal şeklini koruyarak değiştirmeden uygulamaları gerçekleştirmek gerektiği savunulmaktadır. İkinci yaklaşımda önleyici müdahale programının içeriğinin, uygulanışının, sıklığının uygulanacak olan toplumun ihtiyaçlarına göre yeniden şekillendirilmesinin ve uyarlanmasının yapılabileceği açıklanmaktadır (Barrera ve Castro, 2006; Blakeley vd., 1987; Castro, Barrera ve Martinez, 2004; O’Connor vd., 2007; Kumpfer, Alvarado, Smith ve Bellamy, 2002). Ancak bu ikinci yaklaşımda önleyici müdahale programının toplumun ihtiyaçları, değerleri ve kaynakları ile örtüşebilmesi için programın özünden uzaklaşmadan uyarlama çalışmalarının yapılması konusunda özen gösterilmesi üzerinde durulmaktadır. Böylelikle toplumun söz konusu önleyici müdahale programını yüksek seviyede kabullenmeleri sağlanarak uygulanmaların gerçekleştirilmesi ve sürdürülmesi söz konusu olabilecektir. Ancak araştırmacılar bu süreçte uygulayıcıların programın orijinal içeriğini programın uygulanacağı kültürün özeliklerini göz önünde bulundurarak değiştirirken, bir el kitapçı̆̆ı ile bu değişiklikleri açıklamaları ve bunları rapor etmeleri ya da yeni bir modül olarak eklemede bulunmaları üzerinde durmaktadirlar (Diken, Cavkaytar, Batu, Bozkurt ve Kurtyılmaz, 2010; Domitrovich ve Greenberg, 2000; Durlak, 2010). Üçüncü yaklaşım ise toplumun öncülügünde toplum liderleriyle araştırmacıların ortaklığında gerçekleştirilen karşılıklı paylaşımları kapsayan uygulamalardır. Bu noktada hem araştırmacıların toplumsal unsurları bilmesi gerekmekte hem de toplumsal liderlerin araştırma konuları hakkında bir fikir sahibi olması gerekmektedir. Dolayısıyla her iki grubunda bu kapsamda eğitime ihtiyaç duyacakları ifade edilmektedir (O’ Connell vd., 2009). Söz konusu süreçlerde en sık dile getirilen kritik unsur, programın içeriğine bağlılıktaki sapmaların derecesinin beklenen sonuçları da o derece etkileyecek olmasıdır. Bu bağlamda alan yazınında önleyici müdahale programlarının desenini ve sunum şeklini değiştirmeksizin yerel şartları göz önünde bulundurarak uygulamaların gerçekleştirilmesi ve zorluklar üzerinde durularak yerel adaptasyonların yapılması için çözümler araştırılmaktadır. Buradaki en temel kritik unsur ise toplumun özel ihtiyaçlarıyla buluşabilmek için müdahale programının orijinal yapısına bağlı kalarak uyarlama çalışmalarının yapılması ve ikisi arasında dengenin sağlanabilmiş olmasıdır (O'Connor, vd., 2007; U.S. Department of Health and Human Services, 2002). Ancak araştırmacılar henüz bu konuda yeterli bilimsel delillerin toplanamadığ 1 ve ortak fikirlerin beklenen düzeyde gelişemediğini açıklamaktadırlar (O' Connell vd., 2009). Bunlara ek olarak Philipher ve Nolte de (2008) önleyici müdahale programların yaygınlaşması ve başarılı programlar olarak adaptasyon süreçlerini tamamlamaları sırasında programların işlerliğine yönelik bilgi birikiminin yetersizliği üzerinde durmuşlardır. Ayrıca araştırmacılar 
programların toplumun kültürel yapısıyla bağlantılı değerlendirilmelerin sınırlı düzeyde olduğunu ve kaynakların da istenilen düzeyde olmadığını belirterek bu tür zorlukların aşılması gerektiği üzerinde durmaktadır. Spoth Kavanagh ve Dishion' da (2002) bu konuda kültüre özgü risk ve koruyucu faktörlere önem verilmesi gerektiğinin altını çizmişlerdir. $\mathrm{Bu}$ alandaki çalışmaların arttırılmasına ihtiyaç duyulduğunu açıklamışlardır. Ancak literatürde her ne kadar konuyla ilgili ulaşılan noktanın yeterli düzeyde olmadığ de müdahale biliminde kültürel hassaslığı arttıracak stratejilerin geliştirilmesinin gerekliliği üzerinde görüşler yoğun bir şekilde tartışılmakta ve fikir birliğine varılmaya çalışılmaktadır (Aos, Lieb, Mayfield, Miller ve Pennucci 2004; CPRG, 1999; Elias ve Tobias, 1996; Ellliott ve Mihalic, 2004; Hill vd., 2007; Kumpfer vd., 2002; O’Connor vd., 2007; Weisz, Hawley, Pilkonis, Woody ve Follette, 2000). Önleyici müdahale programlarının uygulandığ toplumsal yapıdaki işleyişi değerlendirmek, program hakkındaki geri bildirimleri almak oldukça kritik bir unsur olarak karşımıza çıkmaktadır. Programlara bağlı kalarak programın standartlarını değiştirmeyecek şekilde söz konusu kültüre uyumlu uygulamaların gerçekleştirilip gerçekleştirilmediğini değerlendirmek gereklidir. Bu noktada programın öğretmenlerin ya da uygulayıcıların beklentilerini ne derece karşıladı̆̆ını belirlemek ve sınıf içinde gereksinim duyulan alanlara yönelik gelişimi sağlayıp sağlamadığını saptamak önemlidir. Buradan elde edilen geri dönütler programların yaygınlaştırılması aşamasında, sürekliliğinin sağlanmasında ve ihtiyaç duyulan revizyonlarda kritik bir rol oynamaktadır. Ancak bu kapsamda önleyici müdahale programlarının etkililiğinin bilimsel olarak kanıtlandığı toplulukların dışında farklı toplumlarda etkililiklerinin sınandığ 1 çalışmaların da yeterli seviyeye ulaşamadığ 1 ifade edilmektedir (O' Connell vd., 2009; Gager, Maurice ve Elias, 1997). Programlarının etkiliğinin diğer kültürde sınandığ1 uygulamalarda süreci etkileyebilecek değişkenlerin yelpazesinin oldukça geniş olması bu süreci daha da zorlaştırabilmektedir. Yurtdışında ve ülkemizde okul öncesi dönemde yaygın olarak kullanılmakta olan önleyici müdahale programlarındaki gelişmelerin, içerik, adaptasyon ve uygulama boyutunda tartışılması ve okul öncesi eğitim programıyla örtüşen benzerliklerinin, farklılıklarının, amaç ve kazanımlarının üzerinde durulması ortak bir bakışın gelişebilmesine katkı sağlayabilecektir. Bu sürecin yaygınlaşma aşamasında olan programlar için destekleyici olacağı düşünülmektedir. Bu kapsamda uygulamalar sırasında karşılaşılan zorlukların belirlenmesi, program hakkındaki geri bildirimlerin alınması ve programın içeriğini etkilemeden ihtiyaç duyulan değişimlerin neler olduğunun belirlenmesi yaygınlaşma çalışmaları için gereklidir. Bu noktada program geliştiriciler ile alandaki uygulayıcılar arasında belli noktalarda fikir birliğine varılabilmesi için iş birliği içinde çalışılmasının gerekliliğine dikkat çekilmektedir. Uygulamalar sırasında programın hangi kısımlarının kritik ve temel bir role sahip olduğu konusunda anlaşmaya varmak bunlardan ödün vermeden değişiklikleri gerçekleştirecek ortak bir bakış geliştirebilmek önemlidir (Aos vd., 2004; Durlak, 2010). Her ne kadar bilimsel olarak kanıtlanmış, ardından alanda sınama uygulamaları gerçekleștirilmiş olan evrensel programların farklı kültürlerde uygulamalar sırasında bir takım zorluklarla karşılaşması olağan bir durum olsa da bu zorlukların ortadan kaldırılabilmesi için bunların açığa çıkartılması önemlidir. Bu çalışmada ADSD 
programı ile ilgili olarak öğretmenlerin programın etkiliği hakkındaki görüşleri, kişisel ve mesleki olarak kendilerine ve çocuklara getirdiği katkıları, uygulamalarda karşılaştıkları güçlüklerinin ortaya çıkartılması amaçlanmaktadır. Böylelikle söz konusu programın okul öncesi eğitim kurumlarında etkili ve sürekli uygulanabilmesi ve yaygınlaşabilmesi için ihtiyaç duyulan gereksinimler saptanmaya çalışılacaktır.

\section{Yöntem}

\section{Araştırma modeli}

Bu çalışmada öğretmenlerin Okul Öncesi Alternatif Düşünme Stratejilerinin Desteklenmesi programının içeriğine amaçlarına etkililiğine, katkılarına ve uygulamada karşılaştıkları güçlüklere, yönelik bakış açılarını belirlemek amacıyla tarama araştırmasına başvurulmuştur. Tarama araştırması anket yada görüşme yapılarak bireylerin tutumlarını, faaliyetlerini, herhangi bir konudaki düşüncelerini ortaya çıkarmak amacıyla yapılan bir araştırma yöntemi olarak tanımlanmaktadır (Christensen, Johnson ve Turner, 2015).

\section{Çalışma Grubu}

$\mathrm{Bu}$ araştırmada İzmir ili Bornova ilçesinde hizmet vermekte olan üniversiteye bağlı okul öncesi eğitim kurumlarında en az bir senedir görev yapan 5 ve 6 yaş grubu öğretmenleri çalışma grubunu oluşturmuştur. Mesleki gelişimlerini sürdürmeye istekli, çeşitli program eğitimlerini almaya gönüllü, yaklaşık 3 ay süren ADSD eğitimlerine katılmış ve program uygulamasını henüz tamamlamış olan 10 kadın öğretmen çalışmada yer almıştır. Öğretmenlerin tam gün görev aldığı bu kurumda MEB tarafından hazırlanmış 36-72 aylık çocuklar için 2006 okul öncesi eğitim programı uygulanmaktadır.

Öğretmenlerin demografik bilgileri değerlendirildiğinde; eğitim düzeyleri dört grupta toplanmıştır. Öğretmenlerin \%60’ 1 (6 öğretmen) meslek lisesi mezunu; \%10’ u (1 öğretmen) Meslek Yüksek Okulu mezunu; \% 20’ si (2 öğretmen) Açık Öğretim Fakültesi mezunu ve $\% 10$ ’ u (1 öğretmen) 4 ylllık üniversite mezunudur. Öğretmenlerin mesleki deneyimleri değerlendirildiğinde ise \%30' unun 0-6 yıl arasında, \%40'ının 7-14 yıl arasında ve \%30' unun 15 yıl ve üzeri mesleki deneyime sahip oldukları tespit edilmiştir. Öğretmenlerin, kurumlarında çeşitli eğitimlere ve seminerlere katılmış olmalarına rağmen önleyici müdahale programlarıyla ilişkili herhangi bir eğitime katılmadıkları saptanmıştır

\section{Veri Toplama Araçları}

Çalışmada Okul Öncesi Alternatif Düşünme Stratejilerinin Desteklenmesi Programı̉nın öğretmenlerin kendilerinin ve çocuklarının sosyal duygusal yeterliliklerine ve davranışlarına yönelik olan etkililiğini değerlendirmek amacıyla Yarı Yapılandırılmış Öğretmen Görüşme Formu kullanılmıştır. Öğretmenlerin ADSD programıyla ilişkili deneyimlerine yönelik geri bildirimleri almak amacıyla Öğretmen Memnuniyet Formu/Teacher Satisfaction Survey (Domitrovich, 
Greeenberg, Cortes ve Kusche, 2005) uygulanmıştır. Öğretmenler hakkında demografik bilgileri edinebilmek için ise Öğretmen Bilgi Formu kullanılmıştır.

\section{Yarı Yapılandırılmış Öğretmen Görüşme Formu}

Çalışmada önleyici müdahale programları üzerinde çalışmakta olan bir klinik psikoloji uzmanı ile görüşme verilerinin betimsel analizi konusunda deneyimli bir araştırmacı tarafından literatür taraması gerçekleştirilerek 7 sorudan oluşan bir taslak görüşme formu hazırlanmıştır. Bu form Okul Öncesi Eğitimi Anabilim Dalı’nda görev yapan iki uzmanın değerlendirilmesine sunulmuş öneriler doğrultusunda gerekli değişiklikler gerçekleştirilerek soru sayısı 5’e düşürülmüştür. Uzmanların görüşleri doğrultusunda, formun görünüş geçerliliği yapılmış araştırmanın amacı ve kapsamını karşıladığı hakkında geri bildirilere ulaşılmıştır. Çalışmada iki uygulama gerçekleştirilerek formun pilot uygulaması sınanmıştır. Yapılan deneme sonunda, soruların anlaşılır bulunduğu görüşmelerde sıkıntı yaşanmadığı gözlenmiştir. Pilot uygulamaların ardından form gerekli düzeltmeler yapılarak araştırmada kullanılmak üzere hazır hale getirilmiştir. Her bir görüşme yaklaşık 25-30 dakika arasında sürmüş ve tüm görüşmeler dijital ses kayıt ve video kayıt cihazlarına kaydedilmiştir. ADSD Programının içeriği, amaçları, süreci ve etkililiği hakkında açık uçlu sorular yoluyla öğretmenlerden detaylı görüşler alınmaya çalışılmıştır. Bu çalışmada bir araştırma konusu ya da bir soru hakkında derinlemesine bilgiler elde edilmesini olanaklı kılan (Büyüköztürk, Çakmak, Akgün, Karadeniz ve Demirel, 2011) görüşme tekniği kullanılmıştır.

\section{Öğretmen Memnuniyet Formu}

Bu form ADSD okul öncesi programının ve değerlendirme kitinin bir parçasıdır (Domitrovich, Greenberg, Kusche, ve Cortes, 2005). Söz konusu form ADSD programını geliştiren araştırmacılar tarafından programın içeriğini ve etkililiğini genel olarak değerlendiren 11 sorudan oluşturulmuş 1-4 puan şeklinde likert tipi bir değerlendirmeyi kapsamaktadır. Bu çalışmada öğretmenlerin uygulamakta oldukları ADSD programıyla ilgili deneyimlerine yönelik geri bildirimlerini almak amacıyla kullanılmıştır. Bu form ile programın içinde yer alan kavramların çocuklar üzerinde ne kadar etkili olduğu ve programın uygulanması sırasında sosyal ve duygusal öğrenme hedeflerine ne kadar ulaşıldığı ile ilgili öğretmen izlenimlerini ortaya çıkarmak hedeflenmiştir. Form araştırmacılar, uzmanlardan ve bir dilbilimciden oluşan bir grup çevirmen tarafından türkçeye çevrilmiştir. Önleyici müdahale alanında ve okul öncesi eğitiminde çalışmakta olan iki uzmanın değerlendirilmesine sunularak formun görünüş geçerliliği yapılmıştır.

\section{Öğretmen Bilgi Formu}

Öğretmen Bilgi Formu, öğretmenlerin eğitim düzeyleri, meslekte çalışma süreleri, çalıştıkları kurumda kaç yıldır görev yapmakta oldukları gibi demografik bilgileri kapsayan bir formdur.

\section{işlem}

Çalışmaya katılacak öğretmenlerden öncelikli olarak Öğretmen Bilgi Formunu doldurmaları istenmiştir. Daha sonra, bu öğretmenler, PATHS programın kuramsal altyapısının anlatıldığı 
ve her hafta 1 saat programın içeriğinin sunulduğu bir eğitim sürecinden geçmişlerdir. Eğitim süresince öğretmenlerden programı düzenli olarak (hafta içi her gün) uygulamaları istenmiştir. Program bitiminin hemen ardından öğretmenlere Öğretmen Memnuniyet Formu verilmiştir ve öğretmenler ile Yarı Yapılandırılmış Öğretmen Görüşme Formu kullanılarak yaklaşık 25-30 dakika süren görüşmeler gerçekleştirilmiştir. Görüşmelerde video kayıt ve ses kayıt teknikleri kullanılmış, ancak bazı öğretmenlerin video çekiminden rahatsız olduklarını belirtmeleri üzerine, görüşmelerin rahat bir şekilde gerçekleşmesini engellememek amacıyla bu öğretmenlerle video kaydı yerine ses kaydı yapılmıştır.

\section{Verilerin analizi}

\section{Yarı Yapılandırılmış Öğretmen Görüşmelerinin Analizi}

Yarı Yapılandırılmış Öğretmen Görüşmesinden elde edilen verilerin analizinde betimsel analize başvurulmuştur. Betimsel analizde amaçlanan, araştırmada elde edilen bulguların düzgün, anlaşılır ve yorumlanmış şekilde okuyucuya aktarılmasıdır (Yıldırım ve Şimşek, 2013). Çalışmada niteliksel verinin sayısal değerlere dönüştürülmesi için tüm görüşmeler, görüşmeleri gerçekleştiren araştırmacı tarafından transkript edilmiş ve diğer uzman araştırmacı tarafından kontrol edilmiştir. Öğretmenlerin her bir soruya verdiği cevaplar bir araya getirilmiş ve bir cevap listesi oluşturulmuştur. Daha sonra cevap listesi araştırmacılar tarafından incelenerek, sorulara ilişkin sık sık vurgulanan konulara ya da temalara yönelik kategorileri belirlemek amacıyla iki araştırmacı tarafından bağımsız bir şekilde ayrı ayrı kodlama formu oluşturulmuştur. Daha sonra bu form kullanılarak görüşmeler kodlanmıştır. Kodlayıcılar-arası güvenirlik, görüş birliği / (görüş birliği + görüş ayrılığı) X 100 formülü ile hesaplanmıştır. Kodlayıcılar-arası güvenirliğin \%85 ile \%100 arasında değiștiği, ortalama güvenirliğin ise \%92,5 olduğu bulunmuştur.

Bu çalışmada güvenirliği arttırmak amacıyla, verilerin tekrar tekrar okunarak ele alınmasına ve elde edilen bulguların sürekli kontrol edilmesine dikkat edilmiştir. Ayrıca çalışmada uygun sayısal analiz yapabilmek amacıyla bu bulgular sayısal dizine sokulmuştur.

\section{Öğretmen Memnuniyet Formu Analizi}

Öğretmen Memnuniyet Anketinden elde edilen veriler betimsel istatistik teknikleri kullanılarak gerçekleştirilmiştir.

\section{Bulgular}

Bu bölümde "Yarı Yapılandırılmış Öğretmen Görüşme Formu” nda toplanan verilerden elde edilen bulgular yer almaktadır. Görüşmeler sonucunda elde edilen bulgular formda yer alan sorulara göre sıralanarak verilmiştir. Bu görüşmelerden elde edilen bulgular, frekanslarına göre gruplandırılmıştır. 
1.Araştırmanın ilk sorusu olarak görüşmeye katılan öğretmenlere ADSD Programının içeriğini ve amaçlarını değerlendirdiklerinde böyle bir programa eğitim sürecinde yer vermeleri konusundaki görüşleri sorulduğunda, öğretmenlerin tamamı ADSD programına eğitim sürecinde yer vermeleri gerektiği görüşünde hem fikir olmuşlardır. Bu doğrultuda öğretmenlerin görüşleri incelendiğinde öğretmenlerin ADSD programının Okul öncesi eğitim programında yer almasının uygun olduğuna yönelik 7 farklı gerekçe sundukları saptanmıştur.

Tablo I.

ADSD Programına Eğitim Sürecinde Yer Vermekle Ilişkili Cevapların Dağılımı

\begin{tabular}{ll}
\hline Kategoriler & $\begin{array}{l}\text { Öğretmenler } \\
\mathrm{f}\end{array}$ \\
\hline ADSD OÖEP’ nın amaç ve kazanımlarına uygun olması & 5 \\
ADSD ek etkinlikleri, sınıftaki etkinliklerle rahat uygulanabilir olması & 5 \\
ADSD programının uygulama süresinin uygun olması & 3 \\
ADSD programının yeni düzenlemelere açı olması & 2 \\
ADSD programından sonra diğer etkinliklere geçişin kolay olması & 1 \\
ADSD programının farklı etkinliklere yer veriyor olması & 1 \\
ADSD programına eklemelerin kolayca yapılabilir olması & 1 \\
ADSD Programının belirli gün ve haftalara uygun etkinlikleri kapsıyor olması & 1 \\
\hline
\end{tabular}

Öğretmenlerin ADSD programının okul öncesi eğitim programında yer almasına yönelik sundukları gerekçeler incelendiğinde öğretmenlerin en sık dile getirdikleri iki gerekçe; ADSD programının okulöncesi eğitim programında yer alan amaç ve kazanımlarla uygun olması (5) ve ADSD programindaki ek etkinliklerin, sınıftaki etkinliklere kolayca adapte edilebiliyor (5) olmasıdır. Ayrıca öğretmenler bu programın uygulama süresini uygun bulduklarını çünkü çok zamanlarını almadığını (3) ifade etmişlerdir. Bunlara ek olarak öğretmenler ADSD programının yeni düzenlemelere açık olduğunu (2) ve ADSD programının uygulandığı çember zamanından sonra gelen günlük eğitim akışındaki etkinliğe geçebilmenin daha kolay bir şekilde gerçekleştiğini (1) bildirmişlerdir. Son olarak, ADSD programının içinde sanat, müzik, hikâye okuma gibi etkinlerin olmasının (1), ADSD programına eklemelerin kolayca yapılabilmesinin (1) ve ADSD’nin belirli gün ve haftalara uygun etkinlikler taşımasının (1) da söz konusu programının okulöncesi programda yer alma gerekçeleri arasında belirtildiği saptanmıştır.

2. Çalışmanın ikinci sorusunda öğretmenlerin tamamı, ADSD programı eğitimi almış olmalarının kendilerinin mesleki ve kişisel yaşantılarına yönelik çeşitli boyutlarda katkılar sağladığı görüşünü bildirmişlerdir. Tablo 2' de ADSD programının öğretmenlerin mesleki ve kişisel özelliklerine yönelik katkıları sunulmaktadır. 
Tablo 2.

ADSD Programının Mesleki ve Kişisel Yaşantıya Katkısına Ilişkin Cevapların Dağılımı

\begin{tabular}{ll}
\hline Kategoriler & $\begin{array}{l}\text { Öğretmenler } \\
\mathrm{f}\end{array}$ \\
\hline Mesleki Katkılar & 3 \\
Duygu düzenlemeyi öğretmek & 2 \\
Çocukları tanımak & 2 \\
Kontrol ve disiplin sağlamak & 2 \\
Duygulara yönelik farkındalığı arttırmak & 1 \\
Çocuk-öğretmen ilişkisinini gelişţirmek & 1 \\
İlişkisel problemleri kolay çözmek & \\
Kişisel Katkılar & 7 \\
Öz düzenleme becerisi geliştirmek & 2 \\
Problem çözme tekniği kullanmak & \\
\hline
\end{tabular}

Öğretmenlerin programın mesleki açıdan katkılarına yönelik görüşleri ayrıntılı incelendiğinde ADSD programının çocukların duygularını nasıl kontrol edeceklerini öğrenmelerine katkıda bulunduğu, kaplumbağa gibi yavaş hareket ederek kendilerini kontrol edebilmelerini (3) desteklediği ifade edilmiştir. Ayrıca programın çocukları tanımaya (2), sınıfta kontrol ve disiplini sağlamaya (2), duygulara yönelik farkındalığı arttırmaya (2), öğretmençocuk ilişkisini geliştirmeye (1), ve çocuklarla olan problemleri daha kolay çözmeye (1) yardımcı olduğu belirlenmiştir. Programın mesleki açıdan sağladığı yararların yanı sıra öğretmenlerin kişisel hayatlarında bir sorun karşısında (kaplumbağa olarak sakinleşme vb.) çeşitli tekniklerle duygu düzenleme becerilerini geliştirmeye çalıştıkları (7) ve programda yer alan problem çözme tekniklerini özel hayatlarında kullandıkları saptanmıştır.

3. Araştırmanın bir diğer bulgusu da öğretmenlerden, sınıflarında uyguladıkları ADSD programını çocuklara getirdiği katkılar açısından değerlendirmeleri istendiğinde öğretmenlerin tamamının programı çocuklar açısından yararlı bulduklarını belirttikleri tespit edilmiştir.

Tablo 3.

ADSD Programının Çocuklar Açısından Etkililiğine Ilişkin Cevapların Dağılımı

\begin{tabular}{ll}
\hline Kategoriler & $\begin{array}{l}\text { Öğretmenler } \\
\text { f }\end{array}$ \\
\hline Çocukların duygulara yönelik farkındalıklarının artması & 8 \\
Problem çözme becerilerini geliștimek & 6 \\
Uyumsuz davranışlarda azalma3 & 3 \\
\hline
\end{tabular}

Tablo 3 incelendiğinde öğretmenler ADSD programının çocukların, duygularını fark etmelerinde, duyguları ile baş edebilmelerinde ve duygularını dile getirmelerinde (8) katkı 
sağladığını ifade ederek çocukların duygulara yönelik farkındalıklarının artmasına yol açtığını belirttikleri görülmüştür. Ayrıca programın çocukların, problem çözme becerilerini geliştirirken (6) aynı zamanda itme, vurma ve şikâyet etme gibi uyumsuz davranışlarını azaltmaya (3) katkı sağladı̆̆ı ögretmenler tarafından ifade edilmiştir.

Tablo 4.

ADSD Programının Uygulanmasında Karşılaşılan Güçlüklere Iliş̧in Cevapların Dağılımı

\begin{tabular}{ll}
\hline Kategoriler & $\begin{array}{l}\text { Öğretmenler } \\
\mathrm{f}\end{array}$ \\
\hline ADSD Programının Güçlükleri & 1 \\
Hikayelerin akıcı olmaması & 1 \\
Bazı duygu kavramlarının küçük yaş grubuna uygun olmaması & 1 \\
Hergün çember zamanında programın uygulanıyor olması & 1 \\
ADSD Programına Yönelik Öneriler & \\
Eğitim döneminin başlangıcından itibaren programın başlatılması & 10 \\
Programın uygulama süresini uzatmak & 7 \\
Müzik etkinliklerinin niteliğinin arttırılması & 4 \\
Mutfak ile ilişkili etkinliklerin programdan çıkarılması & 2 \\
Programın içerisinde yer alan hikayelerin kısaltılması & 1 \\
Programın çember zamanı dışında uygulanması & 1 \\
Övgü listesini hergün kullanmamak & 1 \\
Kuklaların boyutunu değiştirmek & 1 \\
Velilere ADSD programını ayrı bir toplantı ile bildirmek & 1 \\
Program materyallerinin arttıılması & 1 \\
\hline
\end{tabular}

Programın uygulama alanında çözüme ihtiyaç duyulan kritik unsurlarının tartışıldığı ve bunlara yönelik önerilerin araştırıldığı 4. soruya verilen öğretmen görüşleri incelendiğinde, öğretmenlerin az sayıda ve çözüme kolayca ulaşabilecekleri sıkıntılar dile getirdiği gözlenmiştir. Metin ve hikâyeleri akıcı bulmama (1), 4 yaş için bazı duygu kavramlarının ağır olması (1), programın her gün aynı saatte uygulanmasının monotonluk yaratıyor olması (1) öğretmenlerin programın güçlüklerine yönelik belirttikleri ifadelerdir. Öğretmenlerin ADSD programına yönelik önerileri değerlendirildiğinde 10 farklı boyutta öneriler sundukları saptanmıştır. $\mathrm{Bu}$ önerilerden en sık ifade edilenlerinin eğitim döneminin başlangıcından itibaren ADSD programının başlatılması (10), uygulama süresinin uzatılması (7), ek etkinliklerdeki şarkıların melodilerinin daha nitelikli olması (4), kurumlarında mutfak olmadığı için mutfak ile ilişkili ekstra etkinliklerin çıkarılması (2) olduğu tespit edilmiştir. 
Tablo 5.

ADSD Programına Yönelik Ailelerden Gelen Geri Bildirimlere Ilişkin Cevapların Dağılımı

\begin{tabular}{ll}
\hline Kategoriler & Öğretmenler \\
& $\mathrm{f}$ \\
\hline Programı içerik açısından beğenme & 2 \\
Kaplumbağa tekniğini kullanma & 2 \\
Oyuncaklarını paylaşma & 2 \\
\hline
\end{tabular}

ADSD Programına yönelik ailelerden öğretmenlere gelen geri bildirimler incelendiğinde tablo 5' e göre ailelerin programı içerik açısından beğendiklerine (2), çocukların evde kaplumbağa tekniğini kullandıklarına (2) ve evlerine misafir geldiğinde çocukların oyuncaklarını diğer çocuklar ile paylaştıklarına (2) yönelik öğretmenlere geri bildirimler sundukları görülmüştür.

\section{ADSD Programının Memnuniyet Anketinden Elde Edilen Bulgular}

\section{Tablo 6.}

Öğretmenlerin ADSD Programı ile iliş̧kili Memnuniyet Dağılımları

\begin{tabular}{|c|c|c|c|c|}
\hline & $\begin{array}{l}1 \\
\text { Kesinlikle } \\
\text { Katılıyorum }\end{array}$ & $\begin{array}{l}2 \\
\text { Katıliyorum }\end{array}$ & $\begin{array}{l}3 \\
\text { Katılmiyorum }\end{array}$ & $\begin{array}{l}4 \\
\text { Kesinlikle } \\
\text { Katılmiyorum }\end{array}$ \\
\hline & $\begin{array}{l}\mathrm{N} \\
(\%)\end{array}$ & $\begin{array}{l}\mathrm{N} \\
(\%)\end{array}$ & $\begin{array}{l}\mathrm{N} \\
(\%)\end{array}$ & $\begin{array}{l}\mathrm{N} \\
(\%)\end{array}$ \\
\hline $\begin{array}{l}\text { 1.Öğrenciler "Günün ADSD Çocuğu” olmak için istekle } \\
\text { beklerler. }\end{array}$ & $\begin{array}{l}10 \\
(100)\end{array}$ & & & \\
\hline $\begin{array}{l}\text { 2. "ADSD Günün Çocuğu” etkinliğinin çocuğa yönelik } \\
\text { övgüler içermesi çocukların benlik saygısını geliştirmektedir. }\end{array}$ & $\begin{array}{l}7 \\
(70)\end{array}$ & $\begin{array}{l}3 \\
(30)\end{array}$ & & \\
\hline $\begin{array}{l}\text { 3. Öğrenciler, "duygu" kelimelerini anlamada ilerleme } \\
\text { göstermiştir. }\end{array}$ & $\begin{array}{l}8 \\
(80)\end{array}$ & $\begin{array}{l}2 \\
(20)\end{array}$ & & \\
\hline $\begin{array}{l}\text { 4.Öğrenciler empati kurmaya ve başkalarının duygularına } \\
\text { karşı merhamet geliştirmeye başlamışlardır. }\end{array}$ & $\begin{array}{l}4 \\
(40)\end{array}$ & $\begin{array}{l}6 \\
(60)\end{array}$ & & \\
\hline $\begin{array}{l}\text { 5.Öğrencilerin, anlaşmazlıkları çözümleme becerileri } \\
\text { gelişmiştir. }\end{array}$ & $\begin{array}{l}3 \\
(30)\end{array}$ & $\begin{array}{l}7 \\
(70)\end{array}$ & & \\
\hline 6.Öğrencilerin, problem çözme becerileri gelişmiştir. & $\begin{array}{l}6 \\
(60)\end{array}$ & $\begin{array}{l}4 \\
(40)\end{array}$ & & \\
\hline $\begin{array}{l}\text { 7.ADSD, öğrencilerin sınıf içi davranışlarının gelişimine } \\
\text { katkıda bulunmuştur. }\end{array}$ & $\begin{array}{l}7 \\
(70)\end{array}$ & $\begin{array}{l}3 \\
(30)\end{array}$ & & \\
\hline $\begin{array}{l}\text { 8.ADSD programında yer alan etkinlikler sınıf etkinlikleri ile } \\
\text { bütünleşebilir. }\end{array}$ & $\begin{array}{l}6 \\
(60)\end{array}$ & $\begin{array}{l}4 \\
(40)\end{array}$ & & \\
\hline 9.ADSD programı sınıfımda etkili olmuştur. & $\begin{array}{l}6 \\
(60)\end{array}$ & $\begin{array}{l}4 \\
(40)\end{array}$ & & \\
\hline 10.Sınıfımın velileri ADSD programına ilgi göstermişlerdir. & $\begin{array}{l}3 \\
(30)\end{array}$ & $\begin{array}{l}7 \\
(70)\end{array}$ & & \\
\hline $\begin{array}{l}\text { 11.Bir sonraki yıl, sınıfımda ADSD uygulamaya devam } \\
\text { etmeyi planlıyorum. }\end{array}$ & $\begin{array}{l}6 \\
(60)\end{array}$ & $\begin{array}{l}4 \\
(40)\end{array}$ & & \\
\hline
\end{tabular}


Tablo 6'da görüldüğü gibi ankete katılan öğretmenlerin ADSD Programına ilişkin olumlu görüşleri ağırlıklı olarak kesinlikle katılıyorum ve katılıyorum boyutlarında toplanmıştır. Bu bulgularda öğretmenlerin tamamı sınıfındaki öğrencilerin "Günün ADSD Çocuğu” olmak için istekle bekledikleri görüşüne kesinlikle katıldıklarını ifade etmişlerdir. Bunun yanı sıra, öğretmenler ADSD programının çocukların benlik saygısını geliştirdiğini, duygulara yönelik farkındalığı arttırdığını ve empati ve diğerlerinin duygularına karşı hoşgörülü olmalarını sağladığını, problem çözme becerilerini geliştirdiğini ve sınıf içindeki uyumlu davranışları arttırdığını kesinlikle katılıyorum ve katılıyorum boyutlarında yanıtlamışlardır.

Ayrıca öğretmenler ADSD programının sınıflarında etkili olduğunu, okulöncesi eğitim programındaki etkinliklerle bütünleşebileceğini, velilerin de programa ilgi gösterdiklerini ve bir sonraki yıl söz konusu programı uygulamaya devam etmek istediklerini kesinlikle katılıyorum ve katılıyorum boyutlarında açıklamışlardır.

\section{Tartışma}

Önleyici müdahale programlarının amaçlarının söz konusu toplumun gereksinimleriyle ne derece örtüştüğü kritik bir noktadır. Bu bağlamda programların etkililiğine yönelik sonuçların da kapsamlı bir şekilde çok boyutlu değerlendirilmesine gereksinim duyulmaktadır. Çeşitli müdahale programlarının uygulama süreçlerinde oluşturduğu etkilerinin, katkılarının ve zorluklarının değerlendirilmesi etkin programlar olarak yaygınlaşmalarında belirleyici olmaktadır. Bu çalışmanın bulgularında pilot olarak uygulanmaya başlayan ADSD programı hakkında öğretmenlerin genel olarak programa yönelik memnuniyet düzeylerinin oldukça yüksek olduğu görülmüștür. Öğretmenler ADSD programının esnek, yeni düzenlemelere olanaklı ve uygulamakta oldukları okul öncesi eğitim programıyla uyumlu bulduklarını belirtmişlerdir. Ayrıca çalışmada hem çocukların sosyal duygusal gelişimlerine hem de kendilerinin kişisel (öz düzenleme ve sorun çözme gibi) ve mesleki (kontrol ve disiplin sağlamak gibi) gelişimlerine katkı sağladığı sıklıkla dile getirilmiştir.

Shure’a (2001) göre de müdahale programları sadece çocukların sosyal ve problem çözme becerilerine yönelik destek sağlamamaktadır. Öğretmenlerin de sınıfta çatışmalarla nasıl başa çıkabileceklerine yönelik uygun yöntem ve yaklaşım biçimini kazanmalarına, problem çözme becerilerini geliştirmelerine katkıda bulunmaktadır. Nitekim Florez (2011) duygu düzenleme becerisinin etkileşimlerin bir yansıması olarak geliştiğini açıklamaktadır. Dolayısıyla çocukların duygularını nasıl kontrol edecekleri ve düzenleyecekleri yaşadıkları deneyimlere bağlı olarak şekillenmektedir. Bu nedenle sınıfta öğretmenlerin uygun şekilde duygularını düzenlemeleri ve bunları çocuklara aktarmaları; çocukların da öfkelerini, kızgınlıklarını nasıl açığa vuracaklarını anlamalarında bir referans işlevi görmektedir (Denham, 1998). Dolayısıyla bu araştırmadan elde edilen bulgularda da öğretmenler çocuklara duygularını nasıl düzenleyeceklerini öğretmek konusunda kendilerini mesleki olarak donanımlı hissetmekle birlikte öz düzenleme becerilerini ve ilişkisel problemlerini çözmek konusunda kişisel bir gelişim içinde olduklarını açıklamaktadır. Nitekim çalışmanın bulgularında öğretmenler çocukların da problem çözme becerilerinde, 
duygulara yönelik farkındalıklarının gelişmesinde ve uyumsuz davranışların azalmasında olumlu gelişmeler içinde olduklarını ifade etmektedir. Vestal 2001 yılında yürüttüğü çalışmasında da bir dizi müdahale programı uygulamış ve sonuç olarak öğretmenlerin, kendi yaşantılarındaki çatışmalara ilişkin daha derin bir iç görü kazandıklarını ortaya koymuştur. Ayrıca öğretmenler çocuklara ilişkisel problemlerini kendi başlarına çözmelerine izin verebildiklerini ifade etmişlerdir. Böylelikle öğretmenler daha kolaylaştırıcı bir rol üstlenerek kendilerini daha güvende hissettiklerini dile getirmişlerdir. Nitekim okul öncesi ADSD programının etkiliğine yönelik yurtdışında gerçekleştirilen araştırmalarda da bu programın erken çocukluk döneminde duygusal farkındalık oluşturtuğu, duygusal düzenleme becerilerini ve sosyal problem çözme becerilerini geliştirdiği, emosyonel ve davranışsal problemleri azalttığı saptanmıştır. Paylaşma, yardımlaşma, işbirliği içinde çalışma gibi üst düzey sosyal becerilerin gelişmesine de katkıda bulunduğu (Cappella, Frazier, Atkins, Schoenwald ve Glisson, 2008; Domitrovich vd., 2005; Domitrovich ve Greenberg, 2000; Bilir, Karabay, Tuncdemir, Greenberg, Domitrovich, 2017; Kam, Greenberg ve Kusche, 2004; Taylor and Schellinger, 2011; Morris vd., 2014; Webster-Stratton, Reid ve Hammond, 2001). Gallagher ve Mayer de (2008) öğretmenlerin çocuklara karşı yakın ve pozitif bir ilişki biçimi sunabilmeleri durumunda çocukların problem çözme becerilerini daha fazla geliştirebileceklerini savunmaktadır.

Öğretmenlerin çocukların sosyal ve duygusal gelişmelerine destek olabilmeleri için hem bireysel hem de profesyonel olarak kendilerini geliştirmeye dayalı eğitimler almaları gerekmektedir (Beyazkürk ve Kesner, 2005). Araştırmacılara göre okul öncesi eğitim kurumlarında çalışan öğretmenlere uzmanlar tarafından çeşitli hizmet içi eğitimlerin verilmesi kurum içinde sağlıklı ve verimli insan ilişkilerinin oluşumunu desteklemekle birlikte uygun rehberliğin sergilenebilmesinde oldukça önem taşımaktadır (Catron ve Kendall, 1984; Honig ve Wittmer 1996; Jacops, 2001). Türkiye’de gerçekleştirilen önleyici müdahale programlarının sonuçları değerlendirildiğinde (Anlıak, 2004; Coşkun, 2008; Dereli, 2008; Diken vd., 2010; Dinçer, 1995; Dinçer ve Güneysu, 1997) elde edilen kazanımlar bu tür programların olabildiğince hızlı bir şekilde yaygınlaşması gerektiğini düşündürmektedir.

$\mathrm{Bu}$ araştırmada öğretmenlerden programın uygulanması sırasında karşılaştıkları güçlükler hakkında alınan geri dönütler incelendiğinde ise sadece üç öğretmenin bir takım zorluklarla karşılatıklarını ifade ettikleri saptanmıştır. Bu öğretmenler hikâyeleri akıcı bulmamış, bazı duygu kartlarının gelişimsel yaşlarına ağır geldiğini ifade etmiş ve uygulamanın her gün çember zamanında yapılmasını tercih etmemiștir. Ayrıca öğretmenlerin hikâyelerde ve müzik etkinliklerindeki akıcılığı sağlamanın gerekliliği yönündeki görüşlerinin bu programı daha nitelikli uygulanacak bir boyuta getireceğini düşündürmektedir. Bu geri bildirimler programın gelecekteki yaygınlaştırma çalışmaları için okul öncesi edebiyat ve müzik alanında deneyimli uzman kişilerden içeriği bozmayacak ancak akıcılığı sağlayacak çalışmaların yapılmasının gerekliliğini ortaya çıkarmıştır. Bu düzenlemeler sonraki uygulamalardaki aksaklıkları ortadan kaldırabilecek ve niteliği arttıracaktır. Bu çalışmada güçlüklerin yanısıra öğretmenlerden program hakkında öneriler de alınmıştır. Çalışmada yer alan bütün öğretmenler bu programın okul öncesi eğitim programı ile uyumlu olduğunu, eğitim döneminin başlangıcından itibaren programın başlatılmasını ve gün içinde daha uzun süre yer verilmesini 
önermişlerdir. Bu sonuç söz konusu programın Türkiye’deki öğretmenlerin adaptasyon sürecinde kritik bir unsur olan dozu ve içeriğine yönelik bir kısaltma talebinin olmadığını göstermektedir. Diğer taraftan alan yazınında program geliştiriciler tarafından en sık tartışılan unsurların başında programın içeriğine ve dozuna bağlı kalınmadan programların kısaltılarak uygulanmak istenmesi gelmektedir (Dane ve Schneider, 1998; Durlak ve DuPre, 2008; Hill vd., 2007). Ancak araştırmalarda programların dozuna bağlılı̆̆ın sonuçlar üzerinde etkili olduğu belirtilmektedir (Kumpfer vd., 2002). Ayrıca öğretmenlerin istekliliği ve programı benimseme düzeylerinin de sonuçları etkilediği ifade edilmektedir (CPPRG, 1999). Araştırmanın sonuçları bu kapsamda değerlendirildiğinde, elde edilen bulguların umut verici olduğu düşünülmektedir. Bu çalışmada sadece iki öğretmen mutfak etkinliklerinin koşulları uygun olmadığı için programdan çıkarılmasını önermiştir.

Pakistanlı çocuklar için ADSD Programının kültürel adaptasyonunun gerçekleştirildiği bir başka çalışmada da benzer bir bulgu ortaya çıkmıştır. Öğretmenler yiyecek ile ilgili etkinliklerin yapımı sırasında sıkıntı yaşadıklarını belirterek bu etkinliklerin çıkartılması yönünde görüş bildirmişlerdir (Inam, Tarig ve Zaman, 2014). Hill, Maucione ve Hood 2007 yılında gerçekleştirdikleri çalışmada 42 program uygulayıcısının en fazla ifade ettikleri adaptasyon şeklinin değiştirme, çıkarma ve oyunlar ekleme olduğu düşünüldüğünde bu çalışmada elde edilen öneri ve eleştirilerin az sayıda ve çözülebilecek nitelikte olduğu düşünülmektedir. Ancak elde edilen bu geri bildirimlere rağmen bu çalışmada sadece öğretmenlerin program hakkındaki memnuniyet düzeylerinin belirlenmesi çalışmanın bir sınırlılığı olarak düşünülmektedir. Bundan sonraki çalışmalarda programın etkiliğinin farklı gruplarda özellikle düşük sosyokültürel seviyedeki çocuklarla sınanmasının ve anne, baba, çocuklardan geri bildirimler alınarak gerçekleştirilmesinin daha genel değerlendirmeleri olanaklı kılabileceğini düşündürmektedir. Ayrıca çeşitli yaklaşım biçimleriyle (niteliksel, niceliksel, deneysel ya da bunların kombine edildiği) programların etkililiğinin farklı gruplarda ve çok boyutlu bir şekilde değerlendirilmesi ile elde edilen veriler, programlara duyulan bilimsel delilleri arttıracaktır.

Önleyici ve müdahale amaçlı yapılan araştırmalar değerlendirildiğinde farklı programların Türk kültürüne uygun olup olmadığının saptanması, programların risk ve koruyucu faktörler üzerindeki etkilerinin açığa çıkartılması ve buradan elde edilen sonuçların tartışılması, ortak bir görüşün gelişmesine ve bu doğrultuda öncelikli temel ihtiyaçların belirlenmesine katkıda bulunabilecektir. Böylelikle istenen hedefe uygun daha işlevsel müdahale programların geliștirilmesine düşünsel bir katkı sunulmuş olacaktır. Alan yazınında da programların farklı kültürlerde etkililiklerinin, adaptasyonlarının, uygulama süreçlerinin ve yaygınlaştırma çalışmalarının daha fazla irdelenmesine gereksinim duyulduğu belirtilmektedir (Greenberg vd., 2003; Gager vd., 1997; Kumpfer vd., 2002). Örneğin Gager ve arkadaşları da (1997)gerçekleştirilen etkililik çalışmalarının sevindirici boyutlara ulaşmış olduğunu ifade etmekle birlikte bu programların yeterlilik boyutlarını irdeleyen çalışmaların sınırlı seviyede olduğunu düşündüklerini açıklamaktadır. $\mathrm{Bu}$ araştırmada birinci derecede uygulamaların niteliğinden sorumlu olan öğretmenlerden alınan geri bildirimlerin ülkemizde var olan sınırlı sayıdaki müdahalelerden biri olan ADSD programın etkililiğinin sınanmasına ve yeniden gözden geçirilerek daha sonraki uygulamalar için gerekli düzenlemelerin yapılmasına ve alana kazandırılmasına katkıda bulunacağı düşünülmektedir. 


\section{Kaynaklar}

Anlıak, Ş. (2004) Farklı Eğitim Yaklaşımları Uygulayan Okul Öncesi Eğitim Kurumlarında Kişiler Arası Bilişsel Problem Çözme Becerisi Programının Etkisinin İncelenmesi. Yayımlanmış Doktora Tezi, Ege Üniversitesi Sosyal Bilimler Enstitüsü Psikoloji Anabilim Dalı, İzmir: Türkiye.

Aos, S., Lieb, R., Mayfield, J., Miller, M., \& Pennucci, A. (2004). Benefits and costs of the prevention and early intervention programs for youth. Washington State Institude for Public Policy. Olympia, WA. Retrieved Fabruary 02, 2011 from http://www.wsipp.wa.gov/pub.asp?docid=04-07-3901.

Barrera, M., \& Castro, F. G. (2006). A Heuristic framework for the cultural adaptation of interventions. Clinical Psychology Science Practice, 13 (4), 311-316.

Beyazkürk, D. \& Kesner, J. E. (2005). Teacher-child relationships in Turkish and United States ols: A cross-cultural study. International Education Journal, 6 (5), 547-554.

Bilir Seyhan, G., Ocak Karabay, S., Arda Tuncdemir, T. B., Greenberg, M. T., \& Domitrovich, C. (2017). The Effects of Promoting Alternative Thinking Strategies Preschool Program on TeacherChildren Relationships and Children's Social Competence in Turkey. International Journal of Psychology.

Blakeley, C. H., Mayer, J. P., Gottschalk, R. G., Schmitt, N., Davidson, W. S., Roitman,.D. B. et al. (1987). The fidelity-adaptation debate: Implications for the implementation of public sector social programs. American Journal of Community Psychology, 15, 253-268.

Büyüköztürk, Ş., Çakmak, E. K., Akgün, Ö. E., Karadeniz, Ş. \& Demirel, F. (2016). Bilimsel Araştırma Yöntemleri. Ankara: Pegem Akademi.

Cappella, E., Frazier, S.L., Atkins, M. S., Schoenwald, S. K., \& Glisson, C. (2008, September). Enhancing schools' capacity to support children in poverty: An ecological model of school-based mental health services. Adm Policy Ment Health, 35(5), 395-409. doi:10.1007/s10488-008-0182-y.

Castro, F. G., Barrera, M., \& Martinez, C. (2004). The cultural adaptation of prevention interventions: Resolving tensions between fidelity and fit. Prevention Science, 5 (1), 41-45.

Catron, C. E., \& Kendall, E. D. (1984). Staff evaluation that promotes growth and problem solving. Young Children, 39 (6), 61-66.

Christensen, L. B., Johnson, R. B. ve Turner, L. A. (2015). Araştırma Yöntemleri Desen ve Analiz. Ahmet Aypay (Çev. Ed.). Ankara: Anı.

Conduct Problems Prevention Research Group. (CPPRG, 1999). Initial impact of the Fast Track prevention trial for conduct problems. II. Classroom effects. Journal of Consulting and Clinical Psychology, 67, 648-657.

Coşkun, L. (2008). An Adaptation and Pilot Implementation of an Effective Intervention Program Targeting Externalizing Behaviors in Early Childhood. Yayımlanmış Doktora Tezi. Koç Üniversitesi Sosyal Bilimler Enstitüsü Psikoloji Anabilim Dalı, İstanbul: Türkiye.

Dane, A. V. A., \& Schneider, B. H. B. (1998). Program integrity in primary and early secondary prevention: Are implementation effects out of control? Clinical Psychology Review, 18(1), 23-23-45.

Denham, S.A. (1998). Emotional development in young children. New York: The Guilford Press.

Dereli, E. (2008) Çocuklar İçin Sosyal Beceri Eğitim Programının 6 Yas Çocukların Sosyal Problem Çözme Becerilerine Etkisi Yayımlanmış Doktora Tezi, Selçuk Üniversitesi Sosyal Bilimler Enstitüsü Çocuk Gelişimi ve Ev Yönetimi Anabilim Dalı, Konya: Türkiye

Diken, I. H., Cavkaytar, A., Batu, S., Bozkurt, F., \& Kurtyllmaz, Y. (2010). Proje ADYEP: Anasinıfi, ilköğretim birinci ve ikinci sınıflarında anti sosyal davranışları önlemeye yönelik bir erken müdahale programının etkililiği (206K165 nolu TÜBİTAK projesi). 
Dinçer, Ç. (1995) Anaokuluna Devam Eden 5 Yaş Grubu Çocuklarına Kişiler Arası Problem Çözme Becerilerinin Kazandırılmasında Eğitimin Etkisinin İncelenmesi. Çocuk Sağlığı ve Eğitimi Programı Doktora Tezi. Hacettepe Üniversitesi Sağlık Bilimleri Enstitüsü

Dinçer, Ç. ve Güneysu. S. (1997) Examining the effects of problem solving training on the acquisition of interpersonal problem solving skills by 5 years old children in Turkey, International Journal of Early Years Education. 5(1), 37-46.

Domitrovich, C. E., \& Greenberg, M. T. (2000). The study of implementation: Current findings from effective programs for school aged children. Journal of Educational and Psychological Consultation, 11, 193-222.

Domitrovich, C. E., Greenberg, M. T., Kusche, C., \& Cortes, R. (2005). Manual for the Preschool PATHS Curriculum. South Deerfield, MA: Channing-Bete Company.

Durlak, J. A., \& DuPre, E. P. (2008). Implementation matters: A review of research on the influence of implementation on program outcomes and the factors affecting implementation. American Journal of Community Psychology, 41, 327-350.

Durlak, J. A. (2010). The importance of doing well in whatecer you do: A commentary on the special section, "implementation research in early childhood education". Early Childhood Research Quarterly, 25, 348-357.

Elias, M. J., \& Tobias, S. E. (1996). Social problem solving interventıon in the schools. New York: The Guilford School Practitioner Series.

Ellliott, D. S., \& Mihalic, S. (2004). Issues in disseminating and replicating effective prevention programs. Prevention Science, 5 (1), 47-53.

Florez, I.R. (2011). Developing Young Children's Self-Regulation through Everyday Experiences. Young Children, 66 (4), 46-51.

Gager, P. J., Maurice J., \& Elias M. J. (1997). Implementing prevention programs in high-risk environments: Aplications of the resilience paradigm. American Journal of Orthopsychiatry, 67(3), 363-373.

Gallagher, K. C. \& Mayer, K. (2008). Enhancing development and learning through teacher-child relationships. Young Children, 80-87.

Greenberg, M. T., Weissberg, R. P., Zins, J. E., Fredericks, L., Resnik., H., \& Ellias, M. J. (2003). Enhancing school-based prevention and youth development through coordinated social, emotional, and academic learning, American Psychologist, 58 (6/7), 466-474.

Hill, L. G., Maucione, K., \& Hood, B. K. (2007). A focused approach to assessing program fidelity. Prevention Science, 8, 25-34.

Honig, A. S., \& Wittmer, D. S. (1996). Helping children became more prosocial: Ideas for classrooms, families, schools, and communities. Young Children, 51 (2), 62-70.

Inam, A., Tarig, P.N., \& Zaman, S. (2014). Cultural Adaptation of Preschool PATHS Curriculum for Pakistani Children, International Journal of Psychology DOI: 10.1002/IJOP.1209

Jacops, M. G. (2001). Providing the scaffold:a model for early childhood/primary teacher preparation, Early Chilhhood Education Journal, 29(2) 125-130.

Kam, C.-M., Greenberg, M. T., ve Kusché, C. A. (2004) Sustained effects of the paths curriculum on the social and psychological adjustment of children in special education. Journal of Emotional and Behavioral Disorders, 12 (2), 66-78.

Kumpfer, K., Alvarado, R., Smith, P., \& Bellamy, N. (2002). Cultural sensitivity and adaptation in familybased prevention interventions. Prevention Science, 3 (3), 241-246.

Morris, P., Mattera, S. K., Castells, N., Bangser, M., Bierman, K., \& Raver, C. (2014). Impact Findings from the Head Start CARES Demonstration: National Evaluation of Three Approaches to Improving 
Preschoolers' Social and Emotional Competence. OPRE Report 2014-44. Washington, DC: Office of Planning, Research and Evaluation, Administration for Children and Families, U.S. Department of Health and Human Services.

O’Connell, M. E., Boat T., \& Warner, K. E. (Eds.). (2009). Preventing mental, emotional, and behavioral disorders among young people: Progress and possibilities. Committee on the Prevention of Mental Disorders and Substance Abuse Among Children, Youth and Young Adults: Research Advances and Promising Interventions; Institute of Medicine; National Research Council.

O'Connor, C., Small, S. A. Ve Cooney S. M. (2007). Program fidelity and adaptation: Meeting local needs without compromising program effectiveness, What Works, Wisconsin - Research to Practice Series, 4. Madison, WI: University of Wisconsin-Madison/Extension.

Philipher, S. ve Nolte, K. (2008). Implementation science: promoting science - based approaches to prevention pregnancy. Prev Sci, 9, 166-177.

Shure, M. B. (2001). I can problem solve (An interpersonal cognitive problem-solving program) (ICPS) (2nd ed). Illinois: Research Press.

Spoth, R. L., Kavanagh, K., \& Dishion, T. J. (2002). Family-centered preventive intervention science: Toward benefits to larger populations of children, youth, and families. In R. L. Spoth, K. Kavanagh \& T. J. Dishion (Eds.), Universal family-centered prevention strategies: Current findings and critical issues for public health impact [Special issue]. Prevention Science, 3, 145-152.

U.S. Department of Health and Human Services. (2002). Finding the balance: Program fidelity and adatation in substance abuse prevention: A state of the art review.

Vestal, M.A. (2001). How Teacher Training in Conflict Resolution and peace education influences relationships and interactions in Head Start Centers. 2001, Doctoral dissertation, Nova Southeastern University. Dissertation Abstracts International, AAT3003729.

Webster-Stratton, C., Reid, J. ve Hammond, M. (2001). Social skills and problem - solving training for children with early-onset conduct problems: Who benefits? Journal of Child Psychology and Psychiatry and Allied Disciplines, 42(7), 943 - 952.

Weisberg, R. P., \& Greenberg, M. T. (1998). Prevention science and colloborative action research: Combining the best from both perspectives. Journal of Mental Health, 7 (5), 479-492.

Weisz J. R., Hawley, K. M., Pilkonis, P.A., Woody, S. R., \& Follette, W. C. (2000). Stressing the (other) three RS in the search for empirically supported treatments. Clinical Psychology: Science and Practice and the Public Interest, 17 (3), 243-258.

Yıldırım, A. \& Şimşek, H. (2013). Sosyal Bilimlerde Nitel Araştırma Yöntemleri. Ankara: Seçkin. 
